\title{
Analysis of the Effect of Profitability, Company Size and Leverage on Tax Avoidance (Study on Go Public Companies in Indonesia)
}

\author{
Sri Ernawati ${ }^{1}$, Grahita Chandrarin ${ }^{2}$, Harianto Respati $^{3}$ \\ ${ }^{1}$ Doctoral Program University of Merdeka Malang, and STIE Indonesia Banjarmasin, Indonesia \\ ${ }^{2-3}$ Graduate Program, University of Merdeka Malang, Indonesia
}

\begin{abstract}
This study aims to obtain evidence of the effect of profitability, company size, and leverage on tax avoidance. Research using quantitative data includes profitability proxied by Return On Assets, company size, leverage and tax avoidance which is proxied through the Cash Effective Tax Rate (CETR). Public companies in Indonesia for the period 20132017 as the study population while the sample in this study were public companies included in the manufacturing industry sector. Sampling using a purposive sampling method. Statistical analysis shows that there is a correlation between profitability and leverage. For this reason, profitability variables are not included in subsequent analyses. The results of the research have found empirical evidence that leverage has a significant effect on tax avoidance on publicly traded companies in Indonesia. The higher the leverage the higher the tax avoidance. As for the size of the company did not find empirical evidence significant effect on tax avoidance.
\end{abstract}

Keywords: Tax avoidance, Profitability, Company size, Leverage.

\section{INTRODUCTION}

Indonesia is currently in the tax sector a major source of state revenue. Approximately more than $85 \%$ of the total national income comes from tax revenue. The amount of the tax revenue target are demanding that the government in this case the Directorate General of Taxation at the Ministry of Finance to work harder to take policy measures certain boost tax revenue among others, by the intensification and extension of tax collection through the expansion of the subject and the object of taxation and to make improvements in the system tax collection.

In line with the above-mentioned government efforts since the last decade (2007 - 2017) the number of taxpayers continues to increase from 4 million taxpayers to 36 million taxpayers. The average growth in the number of taxpayers reached $23.3 \%$ per year, but unfortunately the increase in growth in the number of taxpayers is not followed by the growth of tax revenues. Tax revenue growth in the period 2007-2017 increasingly slowing down, the average decline in tax revenues amounted to $10.3 \%$. Slowing growth in tax revenues has consistently occurred in the period of 2014 through 2017. This phenomenon provides a signal that the taxpayer particular business entity shall always try to do a reduction on the amount of taxes to be paid legally without violating the statutory provisions,

Tax avoidance is one way to legally avoid taxes is not violated tax regulations. Tax avoidance gives an opportunity to the management of an activity that is designed to deliver bad news and mislead investors (Desai and Dharmapala, 2006). The management company can manage with the aim reduce income tax liability of the company. The management can also manipulate revenue and keep the negative information by using the company's tax planning strategies.

Profitability, company size and leverage suspected of Tax avoidance is affecting the company. Profitability inform a company's ability to generate profits for a certain period at the level of sales, assets and certain share capital. Profitability is proxied with return on assets (ROA) is one indicator that reflects the company's financial performance, the higher the ROA value can be achieved by the company then the company's financial performance can be categorized as either. Companies that profit is assumed not to Tax avoidance for being able to adjust the income and tax payments

The size of the company shows a condition or characteristic of an organization or company. Some parameters can be used to determine the size of a company, such as the large number of employees used in the company to conduct operational activities of the company, the amount of assets owned by the company, the total sales achieved by the Company during the period, and the 
number of shares outstanding. The larger the company, the greater the profit obtained, the greater the taxes paid by the company and the more engage company to pay taxes, because taxes are considered a burden for the company

Leverage describes the ability of a company to pay debt used by the company to finance its assets in order to carry out its operational activities. Leverage used by investors to see the company's capabilities and the greater the risk of corporate debt, the greater the risk faced by investors. While companies with large tax burden tends to make loans to reduce the tax burden becomes due. Ozkan (2001) provide evidence that companies that have a high tax liability would choose to get into debt in order to reduce taxes. Companies deliberately owes to reduce the tax burden, it can be mentioned that the company's Tax avoidance.

This study was conducted to test empirically the effect of profitability, size of firms and the leverage against Tax avoidance at the company went public in Indonesia. The first results of this study are expected to enrich the empirical studies on the effect of the size of firms and the leverage profitability related to Tax avoidance on the company go public in Indonesia and further research in the field of Tax avoidance. Both studies can be used as consideration for investors and colon investors who wish to invest in the stock market, especially in the company went public in Indonesia, to provide a signal to investors and investor colon that can become the company's management to save tax by means of Tax avoidance.

\section{LITERATURE REVIEW}

\subsection{Definition, Functions and Role of Taxes}

Taxes as a mandatory contribution of the people to the state coercive and do not receive services in return which is directly used to finance the expenses of the State (Brotodiharjo, 1995) Act No. 16 of 2009 on General Provisions and Tax Procedures which states that the tax is a mandatory contribution to countries that are owed by individuals or entities that are enforceable under the law, by not getting the rewards directly and used for the purposes of state for the greatest prosperity of the people. Thus it is clear that the payment of taxes is a manifestation of the obligations of state and citizen engagement directly and jointly fund the national development is indispensable

Four major functions of tax for the country: first, the function of the budget (budgetary) is also called the fiscal function, namely as a source of cash or financial state. This function shows that the tax is an important aspect of financing and the state revenue because the tax is one source of funds for the country's revenue. Second, the function set (regulation), which the government can use taxation as an aspect that could be used as a tool to achieve a certain goal. Taxes used by the government to regulate and condition specific situations which in essence will make the entire existing situation in a country can benefit the indigenous peoples or communities in the country.

Third, function stability, which the government can use, taxes to regulate or stabilize domestic economy. Taxes become a tool of economic stability in a variety of conditions that might threaten the continuity of the course of the country's economy. With the presence of government tax has a lot of options in making and implementing policy. The four functions of redistribution of income, which taxes the government, can be used for the redistribution of incomes. Taxes are also used to create jobs so that people's income will automatically increase and evenly. So the function of redistribution of income taxes as a form of refund the tax paid to facilitate the people.

Tax is a means for the welfare of the people. For the state to be able to create a sense of fairness in the sharing or distribution of taxes for the community. Justice sharing can be realized if the people obedient and submissive to the government in tax payments. So that taxes can be used as a means of sharing of the community who are able through the hands of the government. Tax distribution containing two-dimensional nature of the force and nature of the willingness of citizens absolutely require government intervention. The nature of coercion needs to be done to provide sanctions to citizens who are able to fulfill the obligation to pay taxes in accordance with applicable law. While the nature of the willingness of citizens is the implementation of common values, concern for fellow citizens share.

\subsection{Tax Avoidance}

Zain $(2007 ; 48-50)$, stated tax avoidance is an action control process in order to avoid the consequences of taxation which is not desired. Tax avoidance is also interpreted as a way to reduce taxes within the limits of the provisions of the tax legislation and may be justified, particularly through tax planning. Wang (2010) defines tax avoidance as a tax deduction explicit per dollar of income before tax. Tax avoidance describes the transfer of wealth from the government to the corporation and should add value to the company. According to Dyreng et al., (2008) it is important to emphasize that Tax avoidance does not necessarily mean the company is involved in an improper.

Tax avoidance often associated with tax planning, both of which use the same legal ways to reduce or even eliminate the tax liability. However, tax planning is not debate about its legitimacy, while Tax avoidance is something that is generally regarded as an unacceptable act. Tax avoidance cannot be released from a view that no laws are violated; Tax avoidance should not be 
prohibited. Everyone has the freedom to manage their own affairs as he wishes, and as long as no laws are violated, the tax authorities can not intervene.

Implementation of self-assessment system provides an opportunity for the taxpayer to reduce the amount of taxes to be paid. Taxpayers, particularly business entities are always working to reduce the cost of the company, including the tax burden. To minimize the amount of tax to be paid. Companies can use two ways: reduce taxes, to keep the value of the applicable tax laws through Tax avoidance or reduce the tax value by taking action that is not in accordance with the law through Tax avoidance. Emptiness or vagueness of the legislation provides a potential basis legally Tax avoidance. Act formulated unclear since legislators include governments and parliaments tend to have different backgrounds, where parliament representing different interests and can be contradictory between one and the other.

\subsection{Profitability, Company Size And Leverage}

Profitability is one of the measurements for the performance of a company. Profitability informs a company's ability to generate profits for a certain period at the level of sales, assets and certain share capital. Profitability is composed of several ratios, one of which is return on assets. Return on Assets (ROA) is an indicator that reflects the company's financial performance, the higher the ROA value can be achieved by the company then the company's financial performance can be categorized as either. Companies that profit is assumed not to Tax avoidance for being able to adjust the income and tax payments.

The size of the company in general can be interpreted as a large or small comparison of an object. Company size is an indicator that can indicate a condition or characteristic of an organization or company. Some parameters can be used to determine the size of a company, such as the large number of employees used in the company to conduct operational activities of the company, the amount of assets owned by the company, the total sales achieved by the Company during the period, and the number of shares outstanding. The larger the company, the greater the profit (profit) obtained, the greater the taxes paid by the company The larger the company, the greater the profit (profit) obtained, the greater the taxes paid by the company and as long as no regulations are violated, the tax authorities cannot intervene.

Leverage is one of the financial ratios that describe the relationship between corporate debt to equity and assets. Leverage describe the source of funds used by the company's operations. leverage also shows the risks faced by the company. Harahap (2013) stated leverage is a ratio that describes the relationship between the company's debt to equity, this ratio can see how far the company is financed by debt or external parties with the ability of companies represented by capital. With a leverage ratio investors can see the extent to which the company is financed by debt or external parties with the ability of companies represented by capital. Debt resulting in the emergence of interest expense that can be used as deduction from taxable income is interest expense arising from loans to third parties or creditors who do not have a relationship with the company.

\subsection{Hypothesis And Conceptual Framework}

Profitability informs a company's ability to generate profits for a certain period at the level of sales, assets and certain share capital. Profitability is composed of several ratios, one of which is return on assets (ROA) as an indicator that reflects the company's financial performance, the higher the ROA value of the company's financial performance can be categorized as either.

Kurniasih (2013) found evidence that profitability is proxied Return on Assets (ROA) significantly against Tax avoidance. Maharani (2014) find evidence that negatively affect the profitability of Tax avoidance (tax avoidance), Saputra et.al (2015) found that significantly affect the profitability of Tax avoidance.Cahyono et.al (2016) provide evidence that profitabilitas measured by (ROA) has no effect on Tax avoidance.Based on that dikemukan hypothesis as follows:

$\mathrm{H}_{1}$ : Profitability significant effect on Tax avoidance

Company size is an indicator that can indicate a condition or characteristic of an organization or company. The larger the company, the greater the financial generated, the greater the tax to be paid by the company. Kurniasih (2013) find Evidence Company size significantly influence Tax avoidance. Swingly (2015) found evidence that size companies positive effect on Tax avoidance. Cahyono et.al (2016) provide evidence that company size has no effect on Tax avoidance. Based on this the following hypotheses are stated:

$\mathrm{H}_{2}$ : Size on the Company's significant effect on Tax avoidance

The greater the debt of the company, the tax burden will be smaller due to increased operating expenses and a reduction element is very meaningful for companies affected by high taxes. Therefore, the higher the interest rate will be higher corporate 
profits from the use of such debt. The benefits arising from tax savings due to interest implications for the increasing use of the company's debt.

Ozkan (2001) provides evidence that companies that have high tax obligations will choose to owe in order to reduce taxes. With the expense of the company in debt to reduce the tax burden, it can be stated that the company is avoiding taxes. Swingly (2015) found evidence that leverage has a negative effect on tax avoidance. Koh \& Lee (2015) found that debt ratios affect financial reporting decisions and corporate tax reporting on a non-monotonous basis depending on the level of debt ratios. If the company's debt ratio is relatively low, it is likely to be aggressive in financial reporting because of the debt ratio increases. Cahyono et.al (2016) provides evidence that leverage has no effect on tax avoidance. Based on the description above stated the hypothesis is as follows:

\section{$\mathrm{H}_{3}$ : leverage significant effect on Tax avoidance}

The conceptual model that will be developed in this study are as follows:

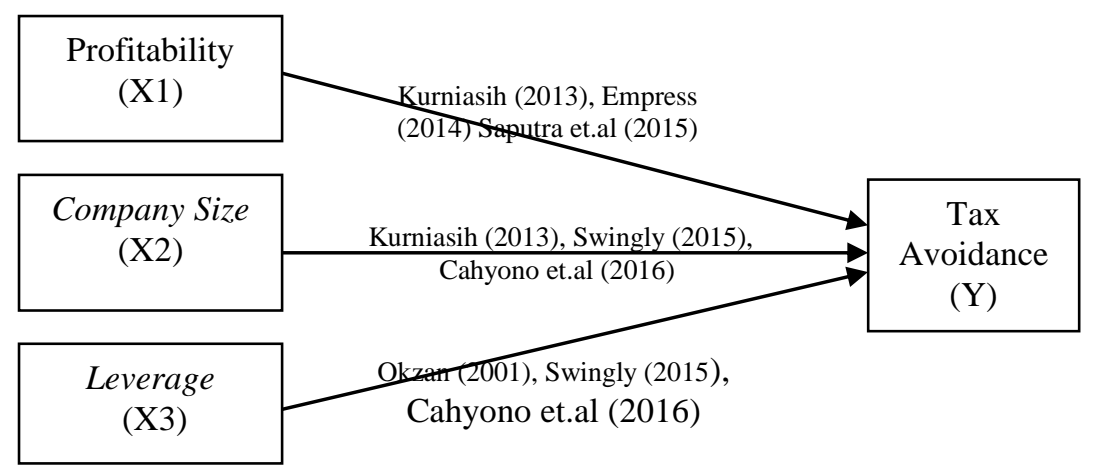

Figure 1. Conceptual Framework

\section{METHODOLOGY}

All companies listed on the Indonesia Stock Exchange 2013-2017 period the population in this study. The sample in this research is included in a group of companies manufacturing sector. Technics of takings samples using purposive sampling, with the following criteria: Companies included in the group listed on the Indonesian stock exchange year period 2013-2017,Publish and publish annual reports (annual report) for 5 consecutive years. As well as having complete data associated with the variables needed in the research.

Researchers used secondary data compiled from the annual financial statements publish manufacturing companies in Indonesia Stock Exchange 2013-2017 period that can be accessed at www.idx.co.id as well as the Indonesian Capital Market Directory, Data collected as many as 66 companies manufacturing, within a period of 5 years (the period from 2013 to 2017).

Measurement of variable to tax avoidance, using methods Cash Effective Tax Rate (CETR). CETR calculated by using the ratio of current income tax expense to the income before tax. For Profitability, proxied by the ratio of Return on Assets (ROA) as measured by the ratio between net income before tax to total assets of the company. Company size is proxied by the natural log $(\mathrm{Ln})$ of total assets. The use of natural $\log (\mathrm{Ln})$, without changing the proportions of the value of the actual origin. Leverage is measured comparing total debt by total assets. On average ROA, company size and leverage in the five years analyzed usingMultiple regression models.

\section{RESEARCH RESULT}

Outlier test was conducted to determine whether there are data values are outliers or the value is very far away from the average and standard deviation. Outlier test done by standardizing the data, if the value of the data after a standardized value is greater than 2.5 or less than -2.5 , then the data are outliers. The solution is not to include the subject of research with the data in the data analysis stage. The test results obtained pencial 8 (eight) the research subjects who had data values that are outliers, namely: UNVR, MLBI, PRAS, KICI, APLI, HMSP, PBRX, and STAR. The eight research subjects, are not included in the analysis stage further, so that the number of research subjects (n) is 58. 


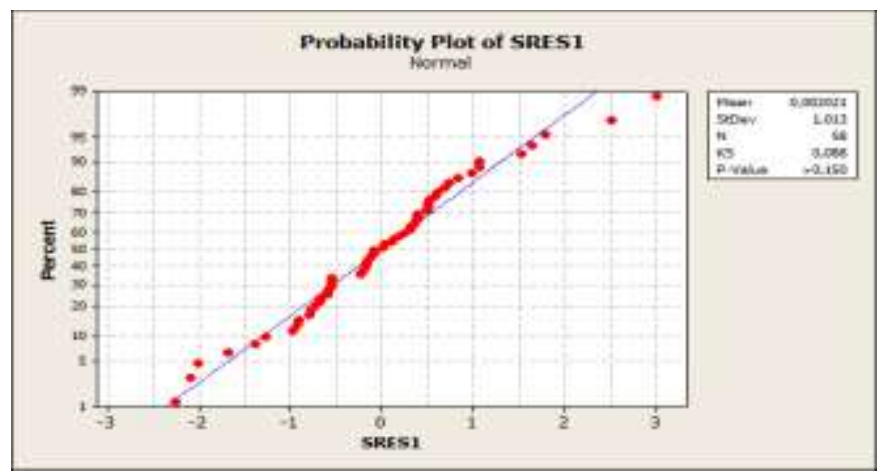

Figure 2 Normality Test Data

Residual normality test results with the Kolmogorov-Smirnov test, the data show the residual follow the normal distribution with ip $=0.15$ is greater than $\alpha=0.05$.

Multicolinearity test shows that there is a correlation between X1 (ROA) and X3 (Leverage) with a correlation coefficient of 0.575. The solution to this problem is to use one variable between $\mathrm{X} 1$ and $\mathrm{X} 3$ as predictor variables together with $\mathrm{X} 2$. Analisis stepwise regression was used to determine the predictor variables are selected among the variables are correlated. The result showed that the variables that should be used or incorporated into the regression equation is variable Leverage (X3) along with the size of the company (X2). Test Multicolinearity company size (X2) and leverage (X3) shown there is no correlation between the two variables.

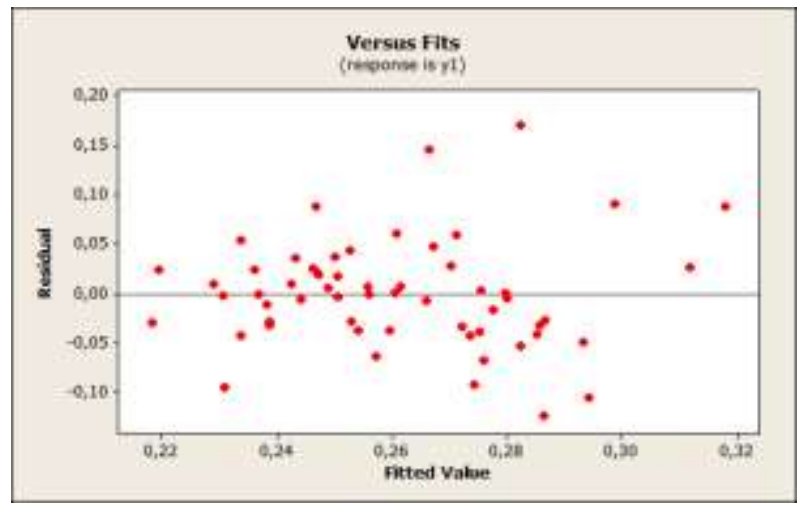

Figure 3 Heteroscedasticity Test

From Figure 2, it appears that the points between the predicted value and the residual value scattered randomly around residual $=$ 0 without forming a specific pattern. This shows that there is no heteroscedasticity.

Table 1: Results of Test of F Statistics

\begin{tabular}{lccccc}
\hline \multicolumn{1}{c}{ Source } & DF & SS & MS & F & P \\
\hline Regression & 2 & 0.028257 & 0.014128 & 4.57 & 0.015 \\
Residual Error & 55 & 0.169893 & 0.003089 & & \\
Total & 57 & 0.198150 & & & \\
\hline
\end{tabular}

Sources of data processed

F-test shows that the p-value of 0.015 which is less than 0.05 . Thus, together (simultaneously), company size (SIZE), and Leverage have a significant influence on the Avoidance of Double Taxation (CETR). Or in other words, multiple linear regression model: $\mathrm{Y}=0.265-0,004 \mathrm{X} 2+0,129 \mathrm{X} 3$ can be used to make predictions on the Avoidance of Double Taxation.

$\mathrm{T}$ test is performed to determine the significance of the effect of each predictor variable to variable partial response. Criteria for decision-making is to reject the hypothesis if the $\mathrm{p}$-value for each predictor variable coefficients greater than $\alpha=0.05$. 
International Journal of Advances in Scientific Research and Engineering (ijasre), Vol 5 (10), October-2019

Table 1: Results of $t$ test

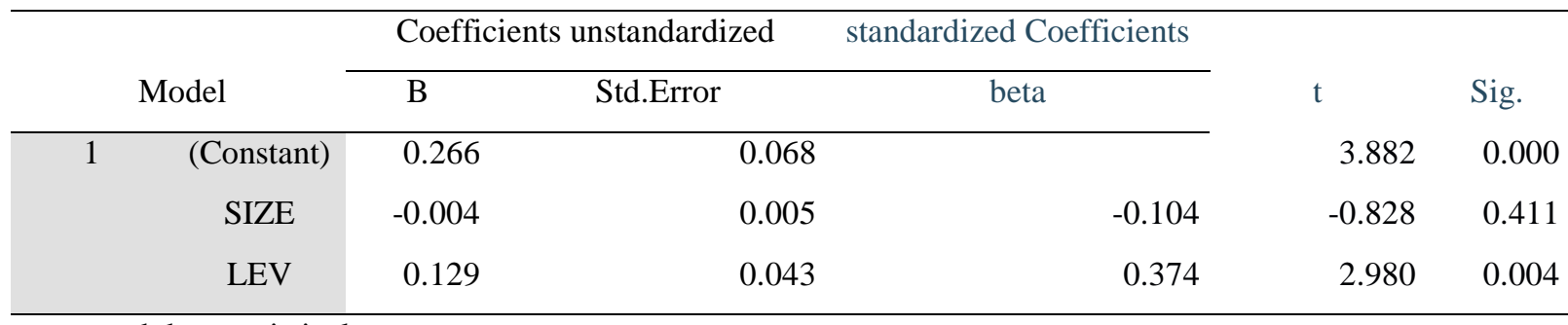

Source: processed data statistical

$\mathrm{T}$ test results, it appears that the $\mathrm{X} 3$ (Leverage) has a value of $\mathrm{p}=0.004$ is less than 0.05 , while $\mathrm{X} 2$ (size of the company) has a value of $p=0.414$ greater than 0.05 . Thus we can say that the leverage has a significant positive effect on the Avoidance of Double Taxation (CETR), or the greater the value the value of leverage, the greater the Tax Treaty. While the size of the company does not have a significant effect on the Avoidance of Double Taxation.

\section{DISCUSSION}

The results show that there has been a correlation between ROA (X1) and variable Leverage (X3) with a correlation coefficient of -0.575 . For that one variable (X1 or X3) is not included in subsequent analyzes. Results of stepwise regression analysis showed that leverage variable (X3) which should be included in the regression equation along with the size of the company (X2), while ROA (X1) as a proxy of profitability should not be included. The findings are not consistent with the findings Kurniasih (2013), Empress (2014) and Saputra et.al (2015) found evidence that profitability is proxied Return on Assets (ROA) significantly against Tax avoidance. And the results findings Cahyono et.al (2016) provides evidence that profitability no effect on Tax avoidance.

For variable sized companies (X2) the value of $p=0.41$ is greater than 0.05 , which means that the size of the company does not have a significant influence on the Avoidance of Double Taxation. Results of the study found no evidence that the size of the company's effect on Tax avoidance. These findings do not support the findings of previous studies conducted Kurniasih (2013) and Swingly (2015) who obtained evidence company size significantly influence Tax avoidance. On the other hand, this study supports the findings of Cahyono et.al (2016) provide evidence that company size has no effect on Tax avoidance.

For variable leverage the value of $p=0.004$ is less than 0.05 . This study successfully obtain proof that leverage significant effect on Tax avoidance. This shows that companies are owed Tax avoidance, as well as the results of research Ozkan (2001) provide evidence that companies that have a high tax liability would choose to get into debt in order to reduce taxes. The results support the results Swingly (2015) found evidence that leverage negative effect on Tax avoidance. Instead research does not support the results of research Cahyono et.al (2016) provide evidence that leverage does not affect the Tax avoidance.

\section{Conclusion}

Tax avoidance is a way of tax saving that is still in the corridor of the law (lawful fashion). Tax avoidance is said to be a complex and unique problem because on one hand it is permissible, but it is undesirable because it can reduce tax revenue. Profitability, company size, and leverage are thought to influence tax avoidance.

The study aimed to determine the effect of profitability, size firms and leverege against Tax avoidance. Simultaneously the research found evidence that the size of the company and leverege significant effect on Tax avoidance with a value of $p=0.015$ is less than 0.05. In partial results of the study only found empirical evidence that leverage significant effect on Tax avoidance, with $\mathrm{p}=0.004$. Meanwhile, company size does not significantly influence Tax avoidance.

The study was limited only to use financial data and do not incorporate elements in analyzing the behavior of Tax avoidance. As is well known that Tax avoidance is an attempt taxpayer or the management of firms to save on taxes through tax planning. In itself an element of tax planning behavior management be very dominant. Subsequent studies need to include behavioral variables, in addition to other variables such as the behavior of tax officials, corporate governance and taxation laws.

\section{REFERENCES}

[1] Brotodiharjoa R Santoso, S.H, 1995, Pengantar Ilmu Hukum Pajak, Edisi ketiga, Cetakan 18, Bandung, Penerbit Eresco

[2] Brigham, Eugene dan Joel F Houston, 2001. Manajemen Keuangan Erlangga, Jakarta.

[3] Chandrarin Grahita, 2017, Metode Riset Akuntansi Pendekatan Kuantitatif, Salemba Empat, Jakarta. 
[4] Cahyono Deddy Dyas, et.al (2016), Pengaruh Komite Audit, Kepemilikan Institusional, Dewan Komisaris, Ukuran Perusahaan (Size), Leverage (DER) dan Profitabilitas (ROA) terhadap Penghindaran Pajak (Tax Avoidance) Pada Perusahaan Perbankan Yang Listing BEI Periode Tahun 2011-2013, Journal Of Accounting, Volume 2 No.2 Maret 2016

[5] Dharmapala, M. A. D. a. D. 2009. Corporate tax avoidance and firm value. The Review of Economics and Statistics August 2009, 91(3): :537-546.

[6] Dyreng, S. D., M. Hanlon, Massachusetts, dan E. L.Maydew. 2010. The effects of executives on corporatetax avoidance. The Accounting Review Vol. 85, No. 4:pp. 1163-1189.10.2308/accr.2010.85.4.1163.

[7] Fahmi, Irham. 2012. Analisis Laporan Keuangan. Cetakan Ke-2. Bandung: Alfabeta.

[8] Frank.et al.. 2009. Tax reporting aggressiveness and its relation to aggressive financial reporting. The Accounting Review Vol. 84, No. 2:pp. 467-496.10.2308/accr.2009.84.2.467.

[9] Guenther David A., E. L. M., Sarah E. Nutter. 1997. Financial reporting, tax costs, and book-tax conformity Journal of Accounting and Economics 23 (1997) 225248.

[10] Harahap, Sofyan Syafri. 2013. Analisis Kritis Atas Laporan Keuangan. Edisi 11. Rajawali Pers, Jakarta.

[11] Johnson, W. B. 1988. Lifo abandonment. Journal of Accounting Research Vol. 26 No. 2 Autumn 1988.

[12] Kurniasih Tommy \& Maria M. Ratna Sari, Pengaruh Return On Assets, Leverage, Corporate Governance, Ukuran Perusahaan dan Kompensasi Rugi Fiskal Pada Tax Avoidance, Buletin Studi Ekonomi, Volume 18, No. 1, Februari 2013 ISSN 1410 4628

[13] Koh Yunsung, Hyun-Ah Lee, 2015. "The effect of financial factors on firms' financial and tax reporting decisions", Asian Review of Accounting, Vol. 23 Issue: 2, pp.110-138

[14] Kourdoumpalou Stavroula and Theofanis Karagiorgos, 2011 Extent of corporate tax evasion when taxable earnings and accounting earnings coincide, Managerial Auditing Journal, Vol. 27 Iss 3 pp. 228 - 250Kim, at. all. 2011. Corporate tax avoidance and stock price crash risk: Firm-level analysis Journal of Financial Economics 10.1016/j.jfineco. 2010.07.007: 639-662.10.1016/j.jfineco.2010.07.007.

[15] Hanlon Michellen and Shane Heitzman, 2010, A Review of Tax Researh, Journal of Accounting and Economics 50 (2010) $127-178$

[16] Maharani I Gusti Ayu Cahya, Ketut Alit Suardana, 2014, Pengaruh Corporate Governance, Profitabilitas dan Karakteristik Eksekutif Pada Tax Avoidance Perusahaan Manufaktur, E-jurnal Akuntansi Universitas Udayana 9.2 (2014) : 525-539.

[17] Munawir S Drs.Ak, 2002, Analisis Informasi Keuangan, edisi Pertama, Liberty Yogyakarta, Yogyakarta

[18] Noor Rohaya Md et.al. 2010. Corporate tax planning: A study on corporate effective tax rates of malaysian listed companies. International Journal of Trade, Economics and Finance, Vol. 1, No. 2

[19] Ozkan, A. 2001. Determinants of Capital Structure and Adjustment to Long-run Target: Evidence from UK Company Panel Data. Journal of Business Financeand Accounting, 28: 175-199.

[20] Saputra Muhammad Fajri at el, 2015, Pengaruh Corporate Governance, Profitabilitas \& Karakter Eksekutif terhadap Tax Avoidance pada Perusahaan yang terdaftar di BEI, JAAI volume 19 No.1, 1-12

[21] Sarwono Jonathan, 2007, Analisis jalur untuk riset bisnis dengan SPSS, Edisi 1, penerbit Andi, Yogyakarta

[22] Scott, William R., 2003. "Financial Accounting Theory". Toronto: Prentice Hall International Inc.

[23] Swingly Calvin, I Made Sukartha, 2015, Pengaruh Karakter Eksekutif, Komiti Audit, Ukuran Perusahaan, Leverage dan Sales Growth Pada Tax Avoidance E-Jurnal Akuntansi Universitas Udayana 10.1 (2015): 47-62

[24] Tang, T., dan M. Firth. 2011. Can book-tax differences capture earnings management and tax management? Empirical evidence from china. The International Journal of Accounting · April 2011.10.1016/j.intacc. 2011.04.005.

[25] White, G. I., Sondhi, A. C., and Dov, F. (2003). The Analysis and Use Of Financial Statements. New York: John Wiley and Sons, Inc.

[26]Zain Mohammad, 2007. Manajemen Perpajakan. Edisi 3, Salemba Empat, Jakarta. 